\title{
Analysis of central corneal thickness in black Cameroonian children
}

\author{
André Omgbwa Eballe' \\ Emilienne Epée ${ }^{2}$ \\ Godefroy Koki \\ Assumpta Lucienne Bella ${ }^{2}$ \\ 'Faculty of Medicine and \\ Pharmaceutical Sciences, University \\ of Douala; ${ }^{2}$ Faculty of Medicine \\ and Biomedical Sciences, University \\ of Yaoundé, Cameroon
}

This article was published in the following Dove Press journal:

Clinical Optometry

25 November 2010

Number of times this article has been viewed
Purpose: Our objective was to determine mean pediatric central corneal thickness (CCT) in black Cameroonian children, according to gender and age, using ultrasonic pachymetry.

Materials and methods: A prospective, observational, consecutive case series in 102 children (204 eyes) aged 5-16 years was carried out from November 2009 to January 2010 at the Eye Unit of the Gynaeco-Obstetric and Paediatric Hospital in Yaoundé, Cameroon. Descriptive and analytic statistics were performed for CCT measured by a hand-held ultrasonic pachymeter (Quantel Medical Inc, Clermont-Ferrand France, Model Pocket, Class II) according to demographic data.

Results: The average CCT for both eyes in these children was $538.06 \pm 38.03 \mu \mathrm{m}$. Average CCT was $541.41 \pm 36.45 \mu \mathrm{m}$ in boys and $536.15 \pm 38.91 \mu \mathrm{m}$ in girls, with no statistically significant difference between the two groups. There was also no statistically significant difference in CCT between the age groups, comprising Group 1 (5-7 years), Group 2 (8-10 years), Group 3 (11-13 years), and Group 4 (14-16 years).

Conclusion: CCT has been suggested to be lower in black children than in Caucasian, Hispanic, and Japanese children. Nevertheless, our average CCT values were within the standard range, varying between 527 and $560 \mu \mathrm{m}$.

Keywords: central corneal thickness, child, Cameroon

\section{Introduction}

Much work has been done on central corneal thickness (CCT). It is as important in children as it is in adults for the diagnosis and management of glaucoma. ${ }^{1,2}$ Studies carried out in children of different races and ethnic groups have revealed a much lower CCT in the African-American child..$^{2-4}$ Data in this area from Cameroon in particular and in the whole of Sub-Saharan Africa in general are limited. The purpose of this study was to determine average CCT in black Cameroonian children aged 5-16 years, while taking note of any differences in CCT according to gender and age.

\section{Materials and methods}

A prospective, observational, consecutive case series in 102 children (204 eyes) aged 5-16 years was carried out from November 2009 to January 2010 at the Eye Unit of the Gynaeco-Obstetric and Paediatric Hospital in Yaoundé, Cameroon, to determine average pediatric CCT according to age and gender using a hand-held ultrasonic pachymeter (Quantel Medical Inc, Clermont-Ferrand France, Model Pocket, Class II). With the exception of ametropia, subjects involved in this study had no eye disease or history of eye surgery. Patients with diabetes, high intraocular pressure, glaucoma, infectious
Correspondence:André Omgbwa Eballe Department of Ophthalmology, Gynaeco-Obstetric and Pediatric Hospital of Yaoundé, PO Box 4362, Yaoundé, Cameroon

Tel +2379965 4468

Fax +23722212430

Email andyeballe@gmail.com 
or inflammatory conjunctival or uveal diseases, and/or using contact lenses were excluded. After written consent from their parents, the children underwent an ophthalmologic examination with evaluation of far visual acuity using a Snellen chart, biomicroscopic examination of the anterior and posterior segments of the eye, and funduscopy. Pachymetry was performed during the day between 8 am and 1 pm by the same examiner, one eye after the other. After corneal anesthesia with $0.4 \%$ oxybuprocaine hydrochloride, an aseptic probe was placed at the center of the cornea on the pupillary axis. The lowest value of three measurements was assumed to be the most representative of the ultrasound probe, placed perpendicular to the central corneal surface, in accordance with the methodology used in previous studies on CCT variations in children. ${ }^{2,4}$ Three measurements of intraocular pressure were also taken using a noncontact tonometer, and the average value was recorded for each eye, which enabled potential cases of glaucoma and ocular hypertonia to be excluded from the study. Therefore, intraocular pressure was not statistically analyzed in this study.

Variables analyzed were gender, age, and CCT in the left and right eyes separately, and then in both eyes together. The population was divided into four groups according to age, ie, Group 1 (5-7 years), Group 2 (8-10 years), Group 3 (11-13 years), and Group 4 (14-16 years).

We used the independent-samples $t$-test and analysis of variance to identify changes in CCT according to gender and age, respectively. Using the Student's $t$-test, we compared our CCT values with those of previous similar studies. Tests were deemed statistically significant if the $P$ value was $<0.05$. The results are presented in Table 1 with averages and standard deviations.

\section{Results}

Of the 102 children who met our inclusion criteria, there were 37 boys (36.27\%) and 65 girls (63.73\%), with an average age of $12.5 \pm 3.1$ years $(95 \%$ confidence interval [CI] 11.92-13.14). Group 4 (14-16 years) was the most representative, with 45 children $(44.12 \%)$.

The average CCT was $539.03 \pm 38.08 \mu \mathrm{m}$ in the right eye (95\% CI 531.55-546.51), 537.09 $\pm 38.16 \mu \mathrm{m}$ in the left eye (95\% CI 529.59-544.58), and 538.06 $\pm 38.03 \mu \mathrm{m}$ in both eyes combined (95\% CI 532.81-543.31, Table 1) with a statistically significant difference between both eyes $(P=0.017)$. The average CCT was $541.41 \pm 36.45 \mu \mathrm{m}$ in boys (95\% CI 532.96-549.85) and 536.15 $\pm 38.91 \mu \mathrm{m}$ in girls (95\% CI 529.40-542.91), with no statistically significant difference between the genders (Table 2).
Table I Mean of central corneal thickness

\begin{tabular}{llll}
\hline CCT & RE $(\mu \mathrm{m})$ & LE $(\mu \mathrm{m})$ & RE+LE $(\mu \mathrm{m})$ \\
\hline Mean \pm SD & $539.03 \pm 38.08$ & $537.09 \pm 38.16$ & $538.06 \pm 38.03$ \\
Minimum & 446 & 442 & 442 \\
Maximum & 638 & 645 & 645 \\
$\mathbf{P}^{*}$ & \multicolumn{2}{c}{$\mathbf{0 . 0 1 7}$} \\
\hline
\end{tabular}

Note: *Paired-samples t-test.

Abbreviations: CCT, central corneal thickness; RE, right eye; $L E$, left eye; RE+LE, right and left eyes combined; SD, standard deviation.

With regard to age, CCT in Group 1 (5-7 years) was $528.08 \pm 37.15 \mu \mathrm{m}$ in both eyes combined (95\% CI 504.48-551.69). Average CCT was higher in Group 2 (8-10 years) at $548.80 \pm 38.23 \mu \mathrm{m}$ in both eyes combined (95\% CI 537.45-560.16); however, there was no statistically significant difference in the other age groups $(P>0.05)$. In Group 3, CCT was $536.30 \pm 38.22 \mu \mathrm{m}$ in both eyes combined (95\% CI 526.07-546.54) and, in Group 4, CCT was $534.99 \pm 37.45 \mu \mathrm{m}$ in both eyes combined (95\% CI 527.15-542.83, Table 3). Table 4 summarizes CCT values in children obtained in studies carried out in Europe, Japan, and the US, and compares these with our values. Table 5 provides a statistical comparison of CCTs in children obtained in these other studies with our mean values.

\section{Discussion}

Our sample, comprising 102 children and corresponding to 204 eyes, enabled us to carry out an analysis of CCT values, although with some reservations while waiting for future studies using a broader sample. The first authors on CCT in children, ie, Ehlers et al, ${ }^{5}$ used optical Haag-Streit pachymetry to provide a basis for collecting pediatric data. In white children aged 2-14 years, they found CCT values $(520 \mu \mathrm{m})$ lower than what we obtained $(538.06 \pm 38.03 \mu \mathrm{m})$ using ultrasonic pachymetry. This might suggest that CCT in black children is higher than in Caucasian children; however, it has been shown that optical pachymetry was less accurate than modern ultrasonic pachymetry. ${ }^{6}$

Using ultrasonic pachymetry, Hussein et $\mathrm{al}^{2}$ showed that CCT in African-American children was lower $(532 \mu \mathrm{m})$ than in Caucasian children $(551 \pm 48 \mu \mathrm{m})$. Similar findings were reported by Muir et al, ${ }^{3}$ who obtained CCT values of $562 \mu \mathrm{m}$ for Caucasian children and $543 \mu \mathrm{m}$ for black children. ${ }^{3}$ Our mean value of $538.06 \mu \mathrm{m}$ was close to those for African-American children found in the aforementioned studies. On the other hand, Dai and Gunderson ${ }^{4}$ found an average CCT of $523 \mu \mathrm{m}$ in African-American children, which is much lower than our mean value. Compared with 
Table 2 Distribution of central corneal thickness according to gender

\begin{tabular}{|c|c|c|c|c|c|c|}
\hline \multirow[t]{2}{*}{ Sex } & \multicolumn{2}{|c|}{$\operatorname{RE}(\mu \mathrm{m})$} & \multicolumn{2}{|c|}{ LE $(\mu \mathrm{m})$} & \multicolumn{2}{|c|}{ RE+LE $(\mu \mathrm{m})$} \\
\hline & $\mathbf{N}$ & Mean \pm SD & $\mathbf{N}$ & Mean \pm SD & $\mathbf{N}$ & Mean \pm SD \\
\hline Male & 37 & $542.11 \pm 37.36$ & 37 & $540.70 \pm 36.03$ & 74 & $54 I .4 I \pm 36.45$ \\
\hline Female & 65 & $537.28 \pm 38.65$ & 65 & $535.03 \pm 39.44$ & 130 & $536.15 \pm 38.91$ \\
\hline Total & 102 & $539.03 \pm 38.08$ & 102 & $537.09 \pm 38.16$ & 204 & $538.06 \pm 38.03$ \\
\hline$P^{*}$ & \multicolumn{2}{|c|}{0.540} & \multicolumn{2}{|c|}{0.473} & \multicolumn{2}{|c|}{0.344} \\
\hline
\end{tabular}

Note: *Independent-samples t-test.

Abbreviations: RE, right eye; LE, left eye; RE+LE, right and left eyes combined; SD, standard deviation.

the reported mean CCT $(544.3 \mu \mathrm{m})$ in Japanese children, ${ }^{7}$ the average CCT of black Cameroonian children was also lower ( $P=0.027$, one-sample $t$-test, Table 5). These observations indicate that race is an important genetic factor that predisposes people to biometric variations. Compared with a study in the nonglaucomatous general Cameroonian population, ${ }^{8}$ in which the average CCT was $528.74 \pm 35.89 \mu \mathrm{m}$, the CCT of children in our series is higher $(P=0.001)$, and is also higher than the adult average CCT, which was $526 \mu \mathrm{m}$ in the aforementioned study $(P=0.001)$.

Research has been carried out using ultrasonic pachymetry in full-term and premature babies following the example of Autzen and Bjornstrom ${ }^{9,10}$ where CCT was $581 \pm 47 \mu \mathrm{m}$ for the Caucasian full-term newborn and $656 \pm 103 \mu \mathrm{m}$ for the premature baby. CCT was $585 \pm 52 \mu \mathrm{m}$ for a full-term newborn according to Remón et al. ${ }^{11}$ All these values when compared with those we obtained in children aged 5-16 years are much higher, indicating a higher CCT at birth. This difference in CCT values between newborns and infants was explained by Ehlers et al, ${ }^{5}$ who showed that the CCT of the baby decreases as the radius of the corneal curvature increases, and reaches adult size at $2-4$ years. However, Bahn et al, ${ }^{12}$ when comparing endothelial cell density in infants and adults, noted a high endothelial cell decrease during the postnatal period, especially when the corneal diameter was in net increase from the infant to adult size, and reported an average endothelial cell density at the center of the cornea of 6000 cells $/ \mathrm{mm}^{2}$ in a newborn and 2500 cells $/ \mathrm{mm}^{2}$ in an adult. ${ }^{12}$ This endothelial cell loss might explain the high decrease in CCT from the first weeks after delivery until reaching adult size at the age of three years. Future studies in this area on black full-term or premature babies might provide values that we can compare with those we have now obtained in infants in order to verify whether CCT is higher in black children.

With regard to age group, a study by Hussein et $\mathrm{al}^{2}$ using ultrasonic pachymetry in a multiracial group of children aged 6 months to 14 years noted a higher CCT $(565 \pm 48 \mu \mathrm{m})$ in the age group 5-9 years, whereas, in our series, children aged 8-10 years had a higher CCT than the other age groups. However, no statistically significant age-related difference was noted in Hussein's series or in our study. In addition, Muir et $\mathrm{al}^{3}$ and Dai et $\mathrm{l}^{4}$ did not find any differences in CCT among various age groups in their pediatric populations, aged $0.75-17$ years and $1-18$ years, respectively. Consequently, it might be thought that CCT in a child older than three years remains stable throughout life. This presupposes a unique biometric constancy in terms of known dimensions. This stability might be acquired following numerous regulatory mechanisms observed from birth, concerning corneal hydration, evaporation, and transparency, reaching adult thickness at 3-5 years. ${ }^{5,9,11}$ The question is whether these phenomena of corneal regulation automatically end when children with $\mathrm{CCT}$ become adults. Is it not possible that these mechanisms

Table 3 Distribution of central corneal thickness according to age

\begin{tabular}{|c|c|c|c|c|c|c|}
\hline \multirow[t]{2}{*}{ Age classes } & \multicolumn{2}{|c|}{$\operatorname{RE}(\mu \mathrm{m})$} & \multicolumn{2}{|c|}{$\operatorname{LE}(\mu \mathrm{m})$} & \multicolumn{2}{|c|}{ RE+LE $(\mu \mathrm{m})$} \\
\hline & $\mathbf{N}$ & Mean \pm SD & $\mathbf{N}$ & Mean \pm SD & $\mathbf{N}$ & Mean \pm SD \\
\hline $5-7$ years & 6 & $532.33 \pm 40.38$ & 6 & $523.83 \pm 36.91$ & 12 & $528.08 \pm 37.15$ \\
\hline $8-10$ years & 23 & $550.96 \pm 39.25$ & 23 & $546.65 \pm 37.93$ & 46 & $548.80 \pm 38.23$ \\
\hline $11-13$ years & 28 & $537.39 \pm 38.75$ & 28 & $535.21 \pm 38.37$ & 56 & $536.30 \pm 38.22$ \\
\hline $14-16$ years & 45 & $534.84 \pm 36.75$ & 45 & $535.13 \pm 38.55$ & 90 & $534.99 \pm 37.45$ \\
\hline Total & 102 & $539.03 \pm 38.08$ & 102 & $537.09 \pm 38.16$ & 204 & $538.06 \pm 38.03$ \\
\hline$P *$ & \multicolumn{2}{|c|}{0.421} & \multicolumn{2}{|c|}{0.502} & \multicolumn{2}{|c|}{0.161} \\
\hline
\end{tabular}

Note: *One-way ANOVA.

Abbreviations: RE, right eye; LE, left eye; RE+LE, right and left eyes combined; SD, standard deviation; ANOVA, analysis of variance. 


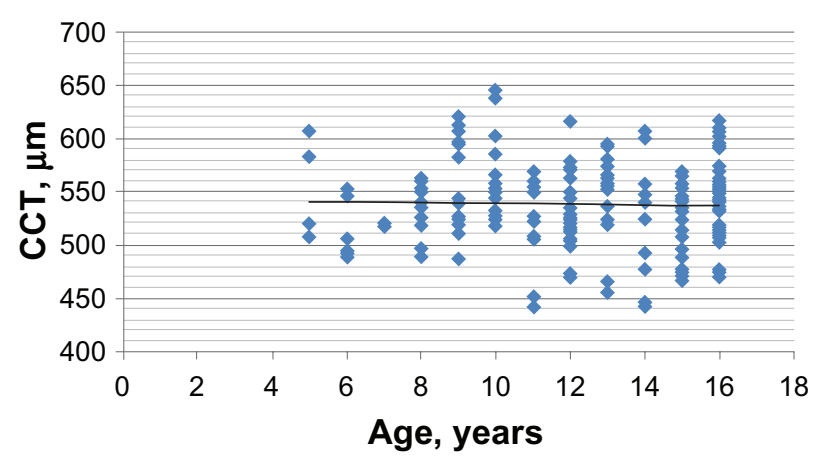

Figure I Variation of CCT according to age (right and left eyes combined). Abbreviation: CCT, central corneal thickness.

continue throughout childhood and even throughout the life of the patient, before other factors come in to cause a decrease of CCT later on in adulthood, given that various studies have confirmed a decrease in CCT with aging. ${ }^{8,13-16}$ These studies have already attempted some explanations for this, including lifestyle, genetic, environmental, social, and economic conditions, ${ }^{17}$ as well as clinical observations, including a decline of endothelial cell density at a slower rate throughout the remainder of life. ${ }^{18-20}$

There was no gender effect on CCT seen in our study. This has been confirmed in other studies of children and adults. ${ }^{3,4,8}$

We found a statistically significant difference between CCT of the right eye and that of the left eye. The difference between both eyes was $1.94 \mu \mathrm{m}$. This difference may be negligible in clinical practice, considering that the manufacturer of the apparatus warns that the measurement accuracy is $\pm 5 \mu \mathrm{m}$ for a measurement range of 125 to $1300 \mu \mathrm{m}$. This difference might be a reflection of measurement uncertainty.

\section{Conclusion}

CCT in black children as measured by ultrasonic pachymetry is lower than in Caucasian, Hispanic, and Japanese children. Nevertheless, these average values remain within the standard range, varying between $527 \mu \mathrm{m}$ and $560 \mu \mathrm{m} .{ }^{21}$ This study has provided a database on CCT in black Cameroonian children. It has also shown that CCT in Cameroonian infants is higher than in adults. An interesting aspect of pachymetry is its ability to categorize patients according to whether they have a thin, normal, or thick cornea, and finally brings out the real value of the intraocular pressure that might be less harmful to the optic nerve. ${ }^{21}$

A limitation of our study was that we did not evaluate variation in intraocular pressure according to CCT in children. We considered that this had been done in previous research involving a sample of the general population of Cameroonians. Another potential limitation of our study involves the actual measurement of CCT, because there was no specific protocol in place to evaluate reproducibility of CCT measurement. Nevertheless, the manufacturer considers that the reproducibility of measurements is $\pm 5 \mu \mathrm{m}$ for structures thicker than $125 \mu \mathrm{m}$.

Table 4 Pediatric central corneal thickness in different population-based surveys

\begin{tabular}{|c|c|c|c|c|c|}
\hline Sources & Populations & $\mathbf{N}$ & Age & Type of pachymeter & CCT $(\mu \mathrm{m})$ \\
\hline \multirow[t]{3}{*}{ Ehlers et $\mathrm{al}^{5}$} & White & 61 children & Zero to 14 years & Optical pachymetry & Premature: 545 \\
\hline & & & & & Full term: 54I \\
\hline & & & & & 2 to 14 years: 520 \\
\hline Portellinha and Belfort J $\mathrm{r}^{22}$ & White & 74 babies & One day & Ultrasonic pachymetry & Full-term newborn: 573 \\
\hline Autzen and Bjornstrom9 & White & 30 babies & One day & Ultrasonic pachymetry & Full-term newborn: 58I \\
\hline Remón et al ${ }^{\prime \prime}$ & White & I52 babies & One day & Ultrasonic pachymetry & Full-term newborn: 585 \\
\hline Autzen and Bjornstrom ${ }^{10}$ & White & I 3 babies & One day & Ultrasonic pachymetry & Premature: 656 \\
\hline \multirow[t]{3}{*}{ Hussein et $\mathrm{al}^{2}$} & White & 110 eyes & 6 months to 14 years & Ultrasonic pachymetry & 551 \\
\hline & Black & 12 eyes & & & 532 \\
\hline & Hispanics & 64 eyes & & & 550 \\
\hline \multirow[t]{2}{*}{ Muir et al ${ }^{3}$} & White & 102 eyes & 9 months to 17 years & Ultrasonic pachymetry & 562 \\
\hline & Black & 66 eyes & & & 543 \\
\hline Hikoya et $\mathrm{al}^{7}$ & Japanese & 338 eyes & 0 to 18 years & Ultrasonic pachymetry & 544.3 \\
\hline \multirow[t]{3}{*}{ Dai and Gunderson ${ }^{4}$} & White & 96 eyes & I to 18 years & Ultrasonic pachymetry & 563 \\
\hline & Black & 45 eyes & & & 523 \\
\hline & Hispanic & 67 eyes & & & 568 \\
\hline \multirow[t]{3}{*}{ Our study } & Black & 204 eyes & $5-16$ years & Ultrasonic pachymetry & 538 \\
\hline & Cameroonian & & & & \\
\hline & children & & & & \\
\hline
\end{tabular}

Abbreviation: $\mathrm{N}$, number of people or number of eyes; CCT, central corneal thickness. 
Table 5 Statistical comparison of Cameroonian pediatric CCT $(538 \mu \mathrm{m})$ vs different population-based survey

\begin{tabular}{|c|c|c|c|}
\hline Sources & Populations & $\mathrm{CCT}(\mu \mathrm{m})$ & $P^{*}$ \\
\hline \multirow[t]{2}{*}{ Hussein et $\mathrm{al}^{2}$} & White & 551 & 0,000 \\
\hline & Hispanics & 550 & 0,000 \\
\hline Muir et $\mathrm{al}^{3}$ & White & 562 & 0,000 \\
\hline Hikoya et $\mathrm{al}^{7}$ & Japanese & 544 & 0,027 \\
\hline \multirow[t]{2}{*}{ Dai and Gunderson ${ }^{4}$} & White & 563 & 0,000 \\
\hline & Hispanic & 568 & 0,000 \\
\hline Non-glaucomatous & Black & 529 & 0,001 \\
\hline \multicolumn{4}{|l|}{$\begin{array}{l}\text { Cameroonian general } \\
\text { population }^{8}\end{array}$} \\
\hline Non-glaucomatous adult & Black & 526 & 0,000 \\
\hline $\begin{array}{l}\text { Cameroonian (aged } 20 \text { years } \\
\text { and older) }\end{array}$ & & & \\
\hline
\end{tabular}

Note: $P^{*}$, one sample $t$-test.

Abbreviation: CCT, central corneal thickness.

\section{Disclosure}

The authors report no conflicts of interest in this work.

\section{References}

1. Brandt JD, Beiser JA, Kass MA, Gordon MO; Ocular Hypertension Treatment Study (OHTS) Group. Central corneal thickness in the Ocular Hypertension Treatment Study. Ophthalmology. 2001;108:1779-1788.

2. Hussein MAW, Paysse EA, Bell NP, et al. Corneal thickness in children. Am J Ophthalmol. 2004;138:744-748.

3. Muir KW, Duncan L, Enyedi LB, Freedman SF. Central corneal thickness in children: Racial differences (black vs white) and correlation with measured intraocular pressure. J Glaucoma. 2006;15:520-523.

4. Dai E, Gunderson CA. Pediatric central corneal thickness variation among major ethnic populations. J AAPOS. 2006;10:22-25.

5. Ehlers N, Sorensen T, Bramsen T, Poulsen EH. Central corneal thickness in newborns and children. Acta Ophthalmol (Copenh). 1976;54:285-290.

6. Salz JJ, Azen SP, Berstein J, Caroline P, Villasenor RA, Schanzlin DJ. Evaluation and comparison of sources of variability in the measurement of corneal thickness with ultrasonic and optical pachymeters. Ophthalmic Surg. 1983;14:750-754.
7. Hikoya H, Sato M, Tsuzuki K, et al. Central corneal thickness in Japanese children. Jpn J Ophthalmol. 2009;53:7-11.

8. Eballe AO, Koki G, Ellong A, et al. Central corneal thickness and intraocular pressure in the Cameroonian nonglaucomatous population. Clin Ophthalmol. 2010;4:717-724.

9. Autzen T, Bjornstrom L. Central corneal thickness in full-term newborns. Acta Ophthalmol (Copenh). 1989;67:719-720.

10. Autzen T, Bjornstrom L. Central corneal thickness in premature babies. Acta Ophthalmol (Copenh). 1991;69:251-252.

11. Remón L, Cristóbal JA, Castillo J, Palomar T, Palomar A, Pérez J. Central and peripheral corneal thickness in full-term newborns by ultrasonic pachymetry. Invest Ophthalmol Vis Sci. 1992;33: 3080-3083.

12. Bahn CF, Glassman RM, MacCallum DK, et al. Postnatal development of corneal endothelium. Invest Ophthalmol Vis Sci. 1986;27: 44-51.

13. Foster PJ, Baasanhu J, Alsbirk PH, Munkhbayar D, Uranchimeg D, Johnson GJ. Central corneal thickness and intraocular pressure in Mongolian population. Ophthalmology. 1998;105:969-973.

14. Cho P, Lam C. Factors affecting the central corneal thickness of Hong Kong-Chinese. Curr Eye Res. 1999;18:368-374.

15. Suzuki S, Suzuki Y, Iwase A, Araie M. Corneal thickness in an ophthalmologically normal Japanese population. Ophthalmology. 2005; 112:1327-1336.

16. Nemesure B, Wu SY, Hennis A, Leske C. Corneal thickness and intraocular pressure in the Barbados Eye Studies. Arch Ophthalmol. 2003;121:240-244.

17. Alsbirk PH. Corneal thickness. 2 Environmental and genetic factors. Acta Ophthalmol. 1978;56:105-113.

18. Bahn CF, MacCallum DK, Patchman MA, et al. Effect of age and keratoplasty on the postnatal development of feline corneal endothelium. Cornea. 1982;1:233.

19. Gwin RM, Lerner I, Warren JK, Gum G. Decrease in canine corneal endothelial cell density and increase in corneal thickness as functions of age. Invest Ophthalmol Vis Sci. 1982;22:267-271.

20. Laule A, Cable MK, Hoffman CE, Hanna C. Endothelial cell population changes of human cornea during life. Arch Ophthalmol. 1978;96: 30-31.

21. Detry-Morel M. Utilité de la pachymétrie cornéenne dans l'hypertension oculaire et le glaucome chronique. Bull Soc Belge Ophtalmol. 2004; 293:1-9.

22. Portellinha W, Belfort Jr. Central and peripheral corneal thickness in newborns. Acta Ophthalmol (Copenh). 1991;69:247-250.
Clinical Optometry

\section{Publish your work in this journal}

Clinical Optometry is an international, peer-reviewed, open access journal publishing original research, basic science, clinical and epidemiological studies, reviews and evaluations on clinical optometry. All aspects of patient care are addressed within the journal as well as the practice of optometry including economic and business analyses. Basic and clinical

\section{Dovepress}

research papers are published that cover all aspects of optics, refraction and its application to the theory and practice of optometry. The manuscript management system is completely online and includes a very quick and fair peer-review system, which is all easy to use. Visit http://www.dovepress. com/testimonials.php to read real quotes from published authors. 